DIAS, Felipe da Veiga; SANTOS, Lucas da Silva. A prisão preventiva em Passo Fundo-RS: análise empírico-criminológica com base nas prisões decretadas em regime de plantão no ano de 2018. Revista Eletrônica Direito e Política, Programa de Pós-Graduação Stricto Sensu em Ciência Jurídica da UNIVALI, Itajaí, v.13, n.3, 30 quadrimestre de 2018. Disponível em: www.univali.br/direitoepolitica - ISSN 1980-7791

\title{
A PRISÃO PREVENTIVA EM PASSO FUNDO-RS: ANÁLISE EMPÍRICO- CRIMINOLÓGICA COM BASE NAS PRISÕES DECRETADAS EM REGIME DE PLANTÃO NO ANO DE 2018
}

\author{
THE PREVENTIVE PRISON IN PASSO FUNDO-RS: EMPIRICAL-CRIMINOLOGICAL
} ANALYSIS BASED ON PRISONS ENACTED ON DUTY REGIME IN THE YEAR 2018

\author{
Felipe da Veiga Dias ${ }^{1}$ \\ Lucas da Silva Santos ${ }^{2}$
}

SUMÁRIO: Introdução; 1 Aportes metodológicos da pesquisa empírica; 2 Perfis do encarceramento na cidade de Passo Fundo; 3 Análise dos discursos de fundamentação utilizados pelos juízes de Passo Fundo/RS: argumentatividade e ideologia hegemônica?; 3.1 Garantia da ordem pública como fundamento orientador nas decisões; 3.2 A reincidência ou primariedade dos réus possuem a mesma relevância?; 3.3 Fumus commissi delicti e periculum libertatis nos decretos prisionais preventivos; 3.4 As medidas cautelares diversas da prisão possíveis alternativas ao encarceramento?; $3.5 \mathrm{~A}$ prisão preventiva (situacional) ou antecipação do cumprimento da pena?; Considerações finais; Referências das fontes citadas.

\section{RESUMO}

O presente estudo possui como tema a prisão preventiva, tendo como problema de pesquisa quais os principais discursos e fundamentos jurídicos em que se baseiam os juízes nos decretos prisionais preventivos? Esses discursos estão atrelados a alguma ideologia? Desse modo, o objetivo central do estudo está na análise dos discursos e fundamentos jurídicos presentes nos decretos prisionais preventivos em regime de plantão na cidade de Passo Fundo/RS, a partir do estudo empírico das decisões judiciais. Assim, utiliza-se o método de abordagem predominantemente indutivo. Soma-se ao método de procedimento monográfico, e a técnica de pesquisa da documentação indireta. Conclui-se que os dados empíricos reforçam a visão nacional no sentido de um discurso punitivo atrelado às decisões judiciais, de modo que a ausência da ruptura discursiva por parte do Judiciário contribui sensivelmente para o incremento do superencarceramento e para a banalização no uso da prisão preventiva como instrumento de punição antecipada.

Palavras-chave: Prisão preventiva; discurso jurisdicional; estudo criminológico empírico, criminologia crítica

1 Pós-doutorando em Ciências Criminais pela PUC/RS. Doutor em Direito pela Universidade de Santa Cruz do Sul (UNISC) com período de doutorado sanduíche na Universidad de Sevilla (Espanha). Professor da Faculdade Meridional (IMED) - Passo Fundo - RS. Brasil. Coordenador do Grupo de Pesquisa "Criminologia, Violência e Sustentabilidade Social" (IMED). Advogado. E-mail: felipevdias@gmail.com.

2 Acadêmico do $10^{\circ}$ semestre da Escola de Direito da IMED. Aluno de iniciação científica da Faculdade Meridional (IMED) - Passo Fundo - RS. Brasil. Integrante dos Grupos de Pesquisa "Criminologia, Violência e Sustentabilidade Social" (IMED), coordenado pelo Prof. Dr. Felipe da Veiga Dias. E-mail: lucassantospf@gmail.com. 
DIAS, Felipe da Veiga; SANTOS, Lucas da Silva. A prisão preventiva em Passo Fundo-RS: análise empírico-criminológica com base nas prisões decretadas em regime de plantão no ano de 2018. Revista Eletrônica Direito e Política, Programa de Pós-Graduação Stricto Sensu em Ciência Jurídica da UNIVALI, Itajaí, v.13, n.3, 30 quadrimestre de 2018. Disponível em: www.univali.br/direitoepolitica - ISSN 1980-7791

\section{ABSTRACT}

The present study has the theme of preventive detention, having as a research problem the main discourses and legal bases on which judges are based on preventive prison decrees? Are these discourses linked to some ideology? Thus, the main objective of this study is the analysis of the discourses and legal foundations present in the preventive prison decrees on duty in the city of Passo Fundo/RS, based on the empirical study of judicial decisions. Thus, the predominantly inductive approach method is used. It is added to the method of monographic procedure, and the research technique of indirect documentation. It is concluded that the empirical data reinforce the national vision towards a punitive discourse linked to judicial decisions, so that the absence of discursive rupture on the part of the Judiciary contributes significantly to the increase of the superimprisonment and the banalization in the use of the preventive prison as an instrument of early punishment.

Keywords: Preventive detention; jurisdictional speech; empirical criminological study, critical criminology

\section{INTRODUÇÃO}

O Brasil atualmente possui a terceira maior população carcerária do planeta, ostentando assustadores 726.712 mil presos, sendo que deste número $40 \%$ são presos provisórios ${ }^{3}$, ou seja, que ainda aguardam por julgamento. Isso apresenta um quadro preocupante quando se observa a atual postura que prioriza a prisão ao invés de buscar alternativas para conter o crescimento contínuo da população carcerária brasileira.

Diante disso, ao debater a política criminal e o modelo de justiça criminal incorporado atualmente pelo Judiciário brasileiro, verifica-se uma aguda e contínua expansão do poder punitivo. Assim, igualmente auxiliada por uma sociedade fundada e enraizada em uma cultura punitivista, potencializa-se o modelo repressivo nacional, resultando na banalização da prisão preventiva e, consequentemente, no superencarceramento em massa ${ }^{4}$.

As estatísticas comprovam o aumento das condenações de encarceramento. Segundo o anuário estatístico da Justiça Criminal produzido pelo Conselho Nacional de Justiça, que confirma a baixa adesão da magistratura nacional às penas alternativas durante o ano de 2015 , as execuções não privativas de liberdade representaram somente $37,1 \%$ de todas

\footnotetext{
3 BRASIL. Levantamento Nacional de Informações Penitenciárias - atualização Junho de 2016. 2017 (a). Disponível em: <http://www.justica.gov.br/news/ha-726-712-pessoas-presas-nobrasil/relatorio_2016_junho.pdf>. Acesso em 25 de março de 2018.

${ }^{4}$ AMARAL, Augusto Jobim do. Política da prova e cultura: a governabilidade inquisitiva no processo penal brasileira contemporâneo. São Paulo: Almedina, 2014, p. 332.
} 
DIAS, Felipe da Veiga; SANTOS, Lucas da Silva. A prisão preventiva em Passo Fundo-RS: análise empírico-criminológica com base nas prisões decretadas em regime de plantão no ano de 2018. Revista Eletrônica Direito e Política, Programa de Pós-Graduação Stricto Sensu em Ciência Jurídica da UNIVALI, Itajaí, v.13, n.3, 30 quadrimestre de 2018. Disponível em: www.univali.br/direitoepolitica - ISSN 1980-7791

as penas aplicadas no país ${ }^{5}$. Ademais, verifica-se de forma quantitativa um número altíssimo de pessoas em privação de liberdade, sem possuir condenação, em sua grande maioria presos preventivos.

O presente estudo possui como objetivo a análise de discursos e fundamentos jurídicos presentes nas decisões judiciais que decretaram as prisões preventivas provenientes do plantão forense da Comarca de Passo Fundo do Estado do Rio Grande do Sul. As decisões consubstanciadas no estudo empírico são referentes aos meses de janeiro a março do ano de 2018. Essas decisões são oriundas de juízes e juízas (Criminais/Cíveis) da Comarca de Passo Fundo/RS, por tratar-se de decisões proferidas em regime de plantão.

Entretanto, antes da discussão ampla deste alto percentual de presos provisórios, a pesquisa parte de algumas indagações: quais os principais discursos e fundamentos jurídicos em que se baseiam os juízes nos decretos prisionais preventivos? Esses discursos estão atrelados a alguma ideologia? Tais questionamentos tem por objetivo apresentar reflexões da prestação jurisdicional em sentido estrito (local), visando dessa forma compreender o percentual elevado de presos preventivos em âmbito nacional, a partir da observação comparativa dos fenômenos específicos constatados na pesquisa de campo.

Assim, se apresentam dados quantitativos obtidos através da análise empírica das decisões judiciais ocorridas no plantão forense, durante o período delimitado, conjuntamente a realização de uma análise qualitativa. Com isso, os dados empíricos possibilitam a verificação entre as construções criminológicas processuais e a realidade enfrentada no plano local e temporal específico delimitado.

$\mathrm{Na}$ segunda etapa, a partir dos dados gerais constatados, busca-se expandir a compreensão, no tocante a banalização do uso da prisão preventiva em nível nacional, que contribui significativamente para superlotações nos presídios.

5 BRASIL. Conselho Nacional de Justiça. Estatísticas revelam aumento das condenações de encarceramento - 2016. Disponível em: <http://www.cnj.jus.br/noticias/cnj/83669-estatisticas-revelamaumento-das-condenacoes-de-encarceramento>. Acesso em 25 de março de 2018. 
DIAS, Felipe da Veiga; SANTOS, Lucas da Silva. A prisão preventiva em Passo Fundo-RS: análise empírico-criminológica com base nas prisões decretadas em regime de plantão no ano de 2018. Revista Eletrônica Direito e Política, Programa de Pós-Graduação Stricto Sensu em Ciência Jurídica da UNIVALI, Itajaí, v.13, n.3, 30 quadrimestre de 2018. Disponível em: www.univali.br/direitoepolitica - ISSN 1980-7791

\section{APORTES METODOLÓGICOS DA PESQUISA EMPÍRICA}

Primeiramente, é de suma importância uma explicação preliminar da estrutura, métodos de abordagem e os métodos de desenvolvimento utilizados na pesquisa de campo. 0 estudo empírico foi realizado partindo da análise das decisões que decretaram as prisões preventivas em regime de plantão dos juízes e juízas da Comarca de Passo Fundo no ano de 2018.

Nessa etapa, utiliza-se predominantemente do método de abordagem indutivo, isto é, busca-se, partindo dos dados particulares constatados por meio do estudo empírico, busca-se uma maior compreensão de quais são os discursos e fundamentos jurídicos dos magistrados no momento da decretação da prisão preventiva. Parte-se de um material inédito, em direção de argumentos que possam alcançar conclusões importantes na compreensão do uso demasiado da prisão preventiva pelos atores da intervenção penal ${ }^{6}$. Esse método é aplicado de forma predominante, porém existem construções dedutivas a serem executadas durante a apreciação dos dados.

Nas etapas da pesquisa, utiliza-se complementarmente a técnica de pesquisa de documentação indireta, alicerçando-se nos fundamentos basilares da criminologia e de um processo penal democrático (marcos teóricos). Desse modo, almeja-se determinar e desconstruir os discursos que buscam legitimar a pena prisão, além de compreender o processo de superencarceramento por meio da decisiva contribuição do Judiciário.

Diante disso, visando um verdadeiro retrato dos discursos judiciais dos magistrados e magistradas da Comarca de Passo Fundo, se faz necessário estabelecer a delimitação de tempo da pesquisa. O recorte temporal se dá nos meses de janeiro a março de 2018, com isso, partindo de um período de análise de três meses do plantão forense, sendo o horário do plantão do foro durante a semana a partir das 17 h30 até as 7h00 do dia seguinte e durante os finais de semana e feriados. Cabe ressaltar que no mês de janeiro, o recesso forense se encerrou no dia vinte, desse modo, todas as ocorrências entre primeiro e vinte de janeiro foram direcionadas ao plantão.

\footnotetext{
${ }^{6}$ MARCONI, Marina de Andrade; LAKATOS, Eva Maria. Fundamentos de metodologia científica. 7 ed. São Paulo: Atlas, 2010, p. 68.
} 
DIAS, Felipe da Veiga; SANTOS, Lucas da Silva. A prisão preventiva em Passo Fundo-RS: análise empírico-criminológica com base nas prisões decretadas em regime de plantão no ano de 2018. Revista Eletrônica Direito e Política, Programa de Pós-Graduação Stricto Sensu em Ciência Jurídica da UNIVALI, Itajaí, v.13, n.3, 30 quadrimestre de 2018. Disponível em: www.univali.br/direitoepolitica - ISSN 1980-7791

Na sede do Poder Judiciário de Passo Fundo, também são julgados os crimes cometidos em outros municípios jurisdicionados da região: Mato Castelhano, Coxilha, Pontão e Ernestina?.

O recorte metodológico dos processos oriundos do plantão forense justifica-se por sua forma de registro manual, já que os demais processos em varas criminais são postos em sistema informatizado e que não distingue quais presos seriam provisórios e quais seriam definitivos, impedindo a presente análise. Registra-se ainda que a pesquisa foi autorizada na data de 14 de dezembro de 2017 pela direção do Foro da Comarca de Passo Fundo.

Sendo assim, a presente pesquisa pretende analisar as decisões dos magistrados de forma completa, não apenas as decisões dos juízes das varas criminais, mas também dos juízes que não atuam em seu cotidiano com a matéria penal. Ressalta-se que, semanalmente, o plantão forense possui um magistrado diferente, possibilitando a melhor identificação das maneiras de pensar e discursos fundamentadores de todos os juízes que atuam na Comarca.

Durante o período delimitado na pesquisa, foram decretados em regime de plantão o total de (22) vinte e dois decretos prisionais preventivos. Todas as ocorrências são escritas manualmente no livro do "plantão do foro". Os servidores plantonistas anotam as seguintes informações: Juiz plantonista, Oficial de Justiça plantonista, data do fato, boletim de ocorrência (se houver), nome do flagrado/investigado, se a prisão em flagrante foi convertida em prisão preventiva, ou, ainda em caso de representação do Ministério Público ou Autoridade Policial o deferimento ou indeferimento do pedido da prisão preventiva.

Os processos identificados com a tramitação "segredo de justiça" foram excluídos e por isso não são objeto da análise empírica. No total foram identificados 06 (seis) processos, dos quais as situações processuais versavam sobre: 01 (um) violência doméstica, 01 (um) latrocínio, 01 (um) estupro de vulnerável, 03 (três) estupros.

Posteriormente, foram acessadas no site do Tribunal de Justiça, em "acompanhamento processual", "ver todas as movimentações" e "conclusos para despacho", todas as 16 (dezesseis) decisões restantes que decretaram as prisões preventivas.

\footnotetext{
7 BRASIL. Tribunal de Justiça do Estado do Rio Grande do Sul. Comarca de Passo Fundo e municípios jurisdicionados. 2018(a). Disponível em: <https://www.tjrs.jus.br/institu/comarcas/dados_comarca.php?codigo=1312>. Acesso em 23 de fevereiro de 2018.
} 
DIAS, Felipe da Veiga; SANTOS, Lucas da Silva. A prisão preventiva em Passo Fundo-RS: análise empírico-criminológica com base nas prisões decretadas em regime de plantão no ano de 2018. Revista Eletrônica Direito e Política, Programa de Pós-Graduação Stricto Sensu em Ciência Jurídica da UNIVALI, Itajaí, v.13, n.3, 30 quadrimestre de 2018. Disponível em: www.univali.br/direitoepolitica - ISSN 1980-7791

As decisões foram proferidas por cinco julgadores diferentes que, no entanto, não serão identificados, pois não se objetiva analisar decisões de magistrados específicos, somente seus discursos e fundamentos jurídicos. Ainda, caso em algum discurso o nome completo do acusado/réu apareça, essa referência será abreviada constando apenas as suas iniciais. Todos os discursos citados estarão referenciados no final da pesquisa com os respectivos números processuais, estando disponível para consultas no site do Tribunal de Justiça do Estado do Rio Grande do Sul.

Para consubstanciar essa análise, primeiramente foram extraídas as seguintes informações de forma quantitativa: (a) Informações do réu: nome, idade, sexo, raça/cor, natureza do crime imputado/praticado, se primário, se reincidente. (b) informações presentes nas decisões: se a prisão ocorreu em flagrante, se houve representação da Autoridade Policial ou do Ministério Público para prisão preventiva; data do fato do crime; data da decisão que decretou a prisão preventiva; duração média da prisão preventiva; qual(is) fundamento(s) principal(is) dos juiz(ízes); julgador que prolatou a decisão; doutrina utilizada na fundamentação, principais discursos.

O presente estudo dos dados ordena-se (predominantemente) por uma apreciação qualitativa, subdividindo-se em três etapas: (1) etapa exploratória, (2) trabalho em campo, (3) análise e tratamento do material empírico documental. Na terceira etapa, para a compreensão dos dados empíricos é necessária a ordenação dos dados extraídos, classificação desses mesmos dados e a análise propriamente dita ${ }^{8}$. Após essa colheita de dados foram extraídos o máximo de elementos possíveis, visando uma análise quantitativa e qualitativa simultaneamente.

As decisões são categorizadas da seguinte forma:

a) Perfis dos réus: nome, idade, sexo, raça/cor, natureza do crime imputado/praticado. Tais dados visam apresentar um retrato dos presos preventivos da Comarca e região, desse modo, verificar a compatibilidade com os dados da população prisional em nível nacional, além de verificar a possível presença desses dados nas decisões por meio de discursos dos julgadores.

b) Os discursos de fundamentação dos decretos prisionais: a seguinte categoria visa identificar quais são os principais fundamentos utilizados no momento da decretação da prisão preventiva, ainda, se esses discursos e argumentos presentes nas decisões são

\footnotetext{
8 MINAYO, Maria Cecília de Souza (org.). Pesquisa social: teoria, método e criatividade. 28. ed.
} Petrópolis, RJ: Vozes, 2009. p. 26-27. 
DIAS, Felipe da Veiga; SANTOS, Lucas da Silva. A prisão preventiva em Passo Fundo-RS: análise empírico-criminológica com base nas prisões decretadas em regime de plantão no ano de 2018. Revista Eletrônica Direito e Política, Programa de Pós-Graduação Stricto Sensu em Ciência Jurídica da UNIVALI, Itajaí, v.13, n.3, 30 quadrimestre de 2018. Disponível em: www.univali.br/direitoepolitica - ISSN 1980-7791

padronizados (repetitivos) ou se modificam em cada caso concreto. Conjuntamente, em decisões proferidas por magistrados diferentes, se é perceptível a presença de discursos semelhantes, ou ainda, maneiras de pensar ou de fundamentar a decisão.

c) A análise da reincidência ou primariedade dos réus: nesse ponto, busca-se verificar os discursos relacionados à reincidência/primariedade ou maus/bons antecedentes, isto é, compreender, a partir dos discursos, qual é a relevância determinada pelos juízes acerca da reincidência ou primariedade.

d) A presença dos requisitos da prisão preventiva: fumus commissi delicti e periculum libertatis. Acerca dos requisitos autorizadores da prisão preventiva, apura-se de que forma são definidos e conceituados pelos magistrados, principalmente, o perigo da liberdade dos réus. Se existem meios probatórios e fáticos que justifiquem o afastamento da liberdade dos réus.

e) As medidas cautelares diversas da prisão: o julgador só pode decretar a prisão preventiva quando não for possível a aplicação de outra medida cautelar, devendo priorizar a medida menos gravosa. Essa categoria visa analisar os argumentos e justificativas dos juízes para a não aplicação das medidas diversas da prisão. Outrossim, verificar a observância dos artigos 282, § $6^{\circ}$ e 312 do Código de Processo Penal.

Diante do exposto, após a explicação preliminar dos aportes metodológicos presentes na pesquisa, abordar-se-ão os dados particulares encontrados durante o estudo, partindo de construções criminológicas processuais e a realidade enfrentada no plano local e temporal específico delimitado.

\section{PERFIS DO ENCARCERAMENTO NA CIDADE DE PASSO FUNDO}

Antes de adentrar na análise das decisões judiciais, traçam-se algumas informações gerais acerca dos réus: nome, idade, sexo, raça/cor, natureza do crime imputado/praticado, se primário ou reincidente. Cabe ressaltar que as informações acerca da escolaridade dos réus não estavam disponíveis em nenhuma situação.

No tocante aos (16) dezesseis processos consubstanciados na análise, verificou-se as naturezas dos crimes imputados/praticados pelos réus, constatando-se que majoritariamente referem-se a crimes de natureza patrimonial, sendo compostos da seguinte forma: Roubo (08) oito, Furto (4) quatro, Produção e Tráfico Ilícito de Drogas (1) um, Receptação (2) dois, Porte ilegal de arma (1) um. 
DIAS, Felipe da Veiga; SANTOS, Lucas da Silva. A prisão preventiva em Passo Fundo-RS: análise empírico-criminológica com base nas prisões decretadas em regime de plantão no ano de 2018. Revista Eletrônica Direito e Política, Programa de Pós-Graduação Stricto Sensu em Ciência Jurídica da UNIVALI, Itajaí, v.13, n.3, 30 quadrimestre de 2018. Disponível em: www.univali.br/direitoepolitica - ISSN 1980-7791

Da totalidade dos processos presentes na análise, no que concerne ao número total de réus, constatou-se o número de (21) vinte e um réus - não significando que cada processo possuísse apenas (1) um réu, tampouco que um único réu figurava somente em um único processo.

Relativamente às informações sobre a raça, cor de pele, na Comarca de Passo Fundo, destaca-se a seguinte composição, dos (21) vinte e um réus, verificou-se: (12) doze de cor branca, (01) um sem informação disponibilizada, (08) oito de cor mista. Em complemento, acerca da idade/faixa etária dos réus: (07) sete entre dezoito a vinte e quatro anos, (06) seis entre vinte e cinco a vinte e nove anos, (04) quatro entre trinta a trinta e quatro anos, (04) quatro acima de trinta e cinco anos. Da totalidade dos réus não figurava nenhuma mulher.

Ao comparar o âmbito regional no qual se situa o presente estudo ao âmbito nacional, no que concerne aos crimes praticados majoritariamente pelas pessoas privadas de liberdade, nota-se que os dados se assemelham, pois no cenário nacional a população prisional é formada majoritariamente por crimes patrimoniais de roubo, furto, combinados com o tráfico, distribuídos da seguinte forma: roubo e furto ( $37 \%)$, tráfico de drogas $(28 \%)$, e homicídios $(11 \%)^{9}$.

O perfil da população carcerária em âmbito nacional, no que se refere a faixa etária é formada em sua grande maioria por pessoas que possuem entre dezoito e vinte e nove anos, representando o percentual de 55\%. No que concerne à raça, cor de pele 64\% da população carcerária brasileira é formada por negros. Segundo o Levantamento Nacional de Informações Penitenciárias, em (13) treze Estados Federativos, o número de negros encarcerados é igual ou superior ao percentual de $80 \%$ de toda a população carcerária ${ }^{10}$.

Cabe mencionar que os dados municipais não apresentam referência à raça do total de sujeitos privados de liberdade ${ }^{11}$, motivo pelo qual o comparativo é feito apenas com base na presente análise empírica e no âmbito nacional, diante da insuficiência de informações do âmbito local e regional.

\footnotetext{
9 BRASIL. Levantamento Nacional de Informações Penitenciárias - atualização Junho de 2016. 2017 (a).

10 BRASIL. Levantamento Nacional de Informações Penitenciárias - atualização Junho de 2016. 2017 (a).

11 Os dados mais recentes dizem respeito apenas à população total do município (sem nenhuma menção aos presos), conforme o Censo 2010. De acordo com a verificação online o município teria cerca de 17\% (31.093 mil pessoas) de pessoas identificadas como não brancas (negros, pardos, amarelos, indígenas). IBGE. Disponível em: <https://sidra.ibge.gov.br/tabela/3175\#resultado>. Acesso em 16 de outubro de 2018.
} 
DIAS, Felipe da Veiga; SANTOS, Lucas da Silva. A prisão preventiva em Passo Fundo-RS: análise empírico-criminológica com base nas prisões decretadas em regime de plantão no ano de 2018. Revista Eletrônica Direito e Política, Programa de Pós-Graduação Stricto Sensu em Ciência Jurídica da UNIVALI, Itajaí, v.13, n.3, 30 quadrimestre de 2018. Disponível em: www.univali.br/direitoepolitica - ISSN 1980-7791

Nessa senda, sobre a atuação do sistema penal, "nada simboliza melhor a seletividade do que a clientela da prisão, ao revelar que a construção (instrumental e simbólica) da criminalidade - a criminalização - incide seletiva e de modo estigmatizante sobre a pobreza e a exclusão social". A seletividade do perfil da população carcerária também decorre da definição do bem jurídico que receberá maior proteção pelo sistema penal, ou seja, visa-se superior proteção aos bens patrimoniais, pois interessam aos cidadãos intitulados de "bem". Por conseguinte, definindo esse bem jurídico, objeto que receberá maior guarida, ocasiona-se maior perseguição e busca por penalização dos indivíduos que os atingem ${ }^{12}$.

O sistema penal funciona estruturalmente, partindo de atuações seletivas, reproduzindo violências e multiplicando condutas lesivas. A corrupção enraizada, conjuntamente à concentração de poder, mais precisamente, o modelo capitalista avançado e o extermínio das relações horizontais, não são particularidades conjunturais e sim estruturais do funcionamento do poder, que visam garantir que esse sistema penal mantenha exatamente a mesma lógica de funcionamento ${ }^{13}$

Resta assim notório que a partir do modelo de sociedade capitalista os crimes contra a propriedade privada obterão maior repressão, excluindo-se aqui as demandas empresariais ou ainda ilícitos das classes mais abastadas ${ }^{14}$, conforme os interesses de ocultação de condutas do Estado.

Em síntese, priorizam-se lesões individuais particularizadas em detrimento da ocultação dos danos coletivos, ficando explícita a relação de quais crimes serão selecionados para receber maior proteção pelo sistema penal e, resultante dessa escolha, qual o perfil será selecionado para ser punido"15. "Sendo assim, em um sistema de classes, enquanto alguns são contemplados com bens positivos como patrimônio, renda e privilégio, a criminalidade é um bem negativo atribuído a algumas pessoas, através de mecanismos

${ }^{12}$ ANDRADE, Vera Regina Pereira de. Pelas mãos da criminologia: o controle penal para além da (des)ilusão. p. 134 - 136.

13 ZAFFARONI, Eugenio Raúl. Em busca das penas perdidas: a perda da legitimidade do sistema penal. 5. ed. Rio de Janeiro: Revan, 2001, p. 15.

14 BARAK, Greg. The crimes of the powerful and the globalization of crime. Revista Brasileira de Direito. Passo Fundo. vol. 11, n. 2, pp. 104-114, jul./dez., 2015, p. 105-106.

15 BARATTA, Alessandro. Criminologia Crítica e Crítica do Direito Penal. Tradução: Juarez Cirino dos Santos. 3. ed. Rio de Janeiro: Revan, 2002. p. 175-176. 
DIAS, Felipe da Veiga; SANTOS, Lucas da Silva. A prisão preventiva em Passo Fundo-RS: análise empírico-criminológica com base nas prisões decretadas em regime de plantão no ano de 2018. Revista Eletrônica Direito e Política, Programa de Pós-Graduação Stricto Sensu em Ciência Jurídica da UNIVALI, Itajaí, v.13, n.3, 30 quadrimestre de 2018. Disponível em: www.univali.br/direitoepolitica - ISSN 1980-7791

análogos", ou seja, a seletividade do sistema orienta-se de acordo com a desigualdade social ${ }^{16}$.

Portanto, o sistema penal é pautado sobre a lógica da exclusão social e a eliminação de determinados indivíduos, o que denota igualmente a ocorrência de um crime de Estado por parte do Brasil. Essa alusão se dá exatamente pelo fato da política criminal contemporânea ocultar determinadas ações, bem como estimular tais processos de aprisionamento estereotipado e proporcionar repetidos casos de eliminação de sujeitos que se encontrariam na esfera de proteção estatal.

Em complemento, no tocante aos dados de cor de pele dos (21) vinte e um réus, tendo em vista nenhum réu ser atribuído/identificado como negro, parece imprescindível o enfretamento dessa informação, visto que tal constatação não corresponde à realidade da população carcerária brasileira, cujo percentual de pessoas negras é de 64\% no cenário nacional ${ }^{17}$.

Sobre os dados que definiram (08) oito réus como de raça/cor de pele "mista", cabe a importante crítica de Carneiro ${ }^{18}$ acerca dessas expressões como pardo, mista, mestiço, que visam em razão de um imaginário social indicar uma melhor aceitação social dos definidos como mais claros em relação aos mais escuros.

A partir dessa perceptiva, é importante abordar acerca das dinâmicas de silenciamento, no tocante à questão racial e sistema penal, que objetivam, baseando-se no mito da democracia racial, evitar a enunciação do racismo não somente pela atuação seletiva do sistema penal, mas também ao negar a existência do racismo no Brasil ${ }^{19}$.

Dentro desse cenário, a estrutura seletiva do sistema penal apresenta uma esfera de atuação desigual tendo como alvo prioritário a população negra. Desta forma, os debates relacionando sistema penal e racismo como uma prática recorrente dos agentes estatais no Brasil costuma ser ocultado.

16 BUDÓ, Marília de Nardin. Mídias e discursos do poder: a legitimação discursiva do processo de encarceramento da juventude pobre no Brasil. Tese (Doutorado em Direito). Universidade Federal do Paraná. Curitiba, 2013. p. 41.

17 BRASIL. Levantamento Nacional de Informações Penitenciárias - atualização Junho de 2016. 2017 (a).

${ }^{18}$ CARNEIRO, Sueli. Racismo, sexismo e desigualdade no Brasil. São Paulo: Selo Negro, 2011. p. 67.

19 FLAUZINA, Ana Luiza Pinheiro. Corpo negro caído no chão: o sistema penal e o projeto genocida do Estado brasileiro. Dissertação (Mestrado em Direito). Universidade de Brasília. Brasília, 2006. p. 3637. 
DIAS, Felipe da Veiga; SANTOS, Lucas da Silva. A prisão preventiva em Passo Fundo-RS: análise empírico-criminológica com base nas prisões decretadas em regime de plantão no ano de 2018. Revista Eletrônica Direito e Política, Programa de Pós-Graduação Stricto Sensu em Ciência Jurídica da UNIVALI, Itajaí, v.13, n.3, 30 quadrimestre de 2018. Disponível em: www.univali.br/direitoepolitica - ISSN 1980-7791

Os discursos institucionais e midiáticos conservam uma narrativa que marginaliza os negros e pobres de forma estrutural, vinculando-os diretamente ao crime e ao perigo, gerando um medo que é disseminado para toda sociedade. Logo, verifica-se com clareza a tentativa de legitimar o exercício do poder repressivo de extermínio do "inimigo", percorrendo não somente nas instituições de controle social, mas, também na população que clama por sua proteção, contra o inimigo tido como criminoso (devido à sua cor de pele e estrato social baixo) ${ }^{20}$.

Consequentemente, a atuação desigual é assegurada pela atividade desempenhada pelo sistema penal, por meio da operacionalização de estereótipos e discriminações, que estão presentes no cotidiano/prática dos agentes estatais, em especial, nas agências policiais, que apresentam em sua esfera de atuação o tratamento desigual como uma prática naturalizada 21 .

Posto isso, ao que tudo indica nesse processo desigual de atuação penal, os dados constatados em âmbito local, de não constar registrado nenhum negro preso durante o período de três meses, são no mínimo questionáveis (ao menos relativamente ao número de sujeitos brancos privados de liberdade).

Todavia, os dados consubstanciados na análise empírica, na qual houve a constatação de que majoritariamente os crimes "em tese" praticados são de natureza patrimonial (roubo e furto), se assemelham com os dados em âmbito nacional. Logo, fica evidente a superior proteção do sistema penal para determinados bens jurídicos ${ }^{22}$.

Ademais, a indagação feita por Carvalho propõe que talvez possua relevância não apenas o bem jurídico definido que receberá maior proteção pelas agências de controle, mas, conjuntamente, o autor da infração, pois os possíveis autores de crimes patrimoniais, como roubo e furto, em regra não se encontram nas classes mais abastadas.

Isso demonstra que o sistema penal busca a seleção de determinados estereótipos, assim etiquetando determinados perfis como "inimigos sociais" que devem ser combatidos. No entanto, o sistema penal seleciona quais estereótipos deve-se deixar de

\footnotetext{
20 STREVA, Juliana Moreira. Auto de resistência, biopolítica e colonialidade: racismo como mecanismo de poder. Revista Brasileira de Ciências Criminais. São Paulo. vol. 138, pp. 237-267, dez., 2017, p. 256.

21 DUARTE, Evandro Piza. Paradigmas em criminologia e relações raciais. Salvador, n.238, pp. 500-526, 2016, p. 519-520.

22 CARVALHO, Salo de. O encarceramento seletivo da juventude negra brasileira: a decisiva contribuição do Poder Judiciário. Belo Horizonte. Revista da Faculdade de Direito UFMG., n. 67, pp. 623-652, jul./dez, 2015, p. 639.
} 
DIAS, Felipe da Veiga; SANTOS, Lucas da Silva. A prisão preventiva em Passo Fundo-RS: análise empírico-criminológica com base nas prisões decretadas em regime de plantão no ano de 2018. Revista Eletrônica Direito e Política, Programa de Pós-Graduação Stricto Sensu em Ciência Jurídica da UNIVALI, Itajaí, v.13, n.3, 30 quadrimestre de 2018. Disponível em: www.univali.br/direitoepolitica - ISSN 1980-7791

lado, ou seja, alguns sujeitos não serão alvo da intervenção penal (como ocorre usualmente com as condutas de colarinho branco ou fraudes e outras condutas no nível de classes sociais mais altas) $)^{23}$.

Em suma, a seleção de determinados indivíduos à criminalização ocorre a partir de uma preconcepção, e a escolha pela persecução busca a punição de determinada conduta (a qual também passa por um processo de seleção, dentre os atos existentes), sendo tipicamente praticada por diversos indivíduos (nas mais variadas classes, etnias ou características), mas que terá sua seletividade determinada com base em um perfil marginalizado. Logo, a aplicação de normas jurídico-penais se dá de forma parcial, de acordo do estereótipo do escolhido.

Assim, a construção de um indivíduo perigoso (do outro), um inimigo de fácil identificação, com um perfil marginal, acaba definindo quais são as respectivas condutas desviantes perante a sociedade. Desse modo, a partir dessa identificação/separação do perigoso ou inofensivo, a punição e, por conseguinte, o encarceramento, produzem (em tese) uma sensação de segurança social, redução de criminalidade e de enfrentamento à impunidade perante a população.

Por fim, a verificação da crítica criminológica acaba sendo referendada em grande parte dos dados colhidos até o momento na Cidade de Passo Fundo, embora existam algumas disparidades na descrição dos acusados ou nas suas características, de igual modo, não afastando a corroboração de uma atuação penal seletiva e violatória. Diante disso, passa-se para a próxima etapa do estudo, o qual se debruça sobre as decisões que decretaram a prisão preventiva dos acusados, em particular sobre os discursos de fundamentação de tais atos.

${ }^{23}$ ZAFFARONI, Eugenio Raúl. Em busca das penas perdidas: a perda da legitimidade do sistema penal. p. 130. 
DIAS, Felipe da Veiga; SANTOS, Lucas da Silva. A prisão preventiva em Passo Fundo-RS: análise empírico-criminológica com base nas prisões decretadas em regime de plantão no ano de 2018. Revista Eletrônica Direito e Política, Programa de Pós-Graduação Stricto Sensu em Ciência Jurídica da UNIVALI, Itajaí, v.13, n.3, 30 quadrimestre de 2018. Disponível em: www.univali.br/direitoepolitica - ISSN 1980-7791

\section{ANÁLISE DOS DISCURSOS DE FUNDAMENTAÇÃO UTILIZADOS PELOS JUÍZES DE PASSO FUNDO/RS: ARGUMENTATIVIDADE E IDEOLOGIA HEGEMÔNICA?}

A prisão preventiva a partir dos artigos 311 a 316 do Código de Processo Penal ${ }^{24}$ traz os requisitos e exigências para sua decretação. Consta dessas previsões que somente pode ser decretada por juiz ou tribunal competente, em decisão fundamentada, podendo ser no curso da investigação ou do processo, a partir da representação do Ministério Público e Autoridade Policial ou ainda em caso de ação penal privada por requerimento do querelante.

Prevê ainda o artigo 311 do referido Código a possibilidade da decretação pelo juiz (de ofício) no curso do processo penal. Lopes Júnior expõe sobre tal possibilidade: "assim, ao decretar uma prisão preventiva de ofício, assume o juiz uma postura incompatível com aquela exigida pelo sistema acusatório e, principalmente, com a estética de afastamento que garante a imparcialidade"25.

As medidas cautelares, como a prisão preventiva, servem para que o Estado promova, em face de requerimento ou representação dos legitimados, imposições que visem garantir obtenção de provas, mediante sua necessidade (em caráter de urgência) ou, ainda, a aplicação da lei penal ou garantia da ordem pública. No entanto, devem estar presentes os requisitos relativos à autoria e materialidade, não bastando meras ilações ou acusações infundadas para utilização da medida excepcional e provisória ${ }^{26}$.

É valioso levar em consideração o registro de Rosa ${ }^{27}$, acerca do uso de termos vagos e imprecisos nos dispositivos legais que delimitam os decretos preventivos, de modo a perceber como se dá tal apreciação de "critérios". Esse alerta corrobora a importância dos conceitos legais (e sua imprecisão) no momento da decisão, devendo ser analisados a partir de uma perspectiva sistemática de interpretação constitucional.

Com isso, a partir da observação das decisões, verifica-se que determinados discursos e fundamentos se repetem majoritariamente (em decisões de juízes diferentes), ainda

${ }^{24}$ BRASIL. Código de Processo Penal. Decreto Lei n³.689, de 03 de outubro de 1941. Disponível em: <http://www.planalto.gov.br/ccivil_03/decreto-lei/Del3689Compilado.htm>. Acesso em: 20 de mar. de 2018.

25 LOPES JÚNIOR, Aury. Prisões Cautelares. 5 ed. São Paulo: Saraiva, 2017, p. 93.

${ }^{26}$ ROSA, Alexandre Morais da. Guia compacto do processo penal conforme a teoria dos jogos. 3 ed. Florianópolis: Empório do Direito, 2016. p. 265.

27 ROSA, Alexandre Morais da. Guia compacto do processo penal conforme a teoria dos jogos. p. 149. 
DIAS, Felipe da Veiga; SANTOS, Lucas da Silva. A prisão preventiva em Passo Fundo-RS: análise empírico-criminológica com base nas prisões decretadas em regime de plantão no ano de 2018. Revista Eletrônica Direito e Política, Programa de Pós-Graduação Stricto Sensu em Ciência Jurídica da UNIVALI, Itajaí, v.13, n.3, 30 quadrimestre de 2018. Disponível em: www.univali.br/direitoepolitica - ISSN 1980-7791

sendo possível verificar variação de relevância dos argumentos. Logo, ora elementos são imprescindíveis para a decretação da prisão preventiva, ora tais elementos não são relevantes para assegurar a liberdade dos acusados, conforme se passa a expor.

\subsection{GARANTIA DA ORDEM PÚBLICA COMO FUNDAMENTO ORIENTADOR NAS DECISÕES}

Relativamente aos fundamentos utilizados pelos magistrados, cabe ressaltar que em todas as decisões consubstanciadas no estudo empírico, a garantia da ordem pública foi utilizada como fundamento determinante para afastar a excepcionalidade das prisões preventivas. Em pouquíssimas decisões, a noção da garantia da ordem pública foi combinada com a paz social ou aplicação da lei penal.

Os discursos de reiteração delitiva, como autorizadores da segregação para garantia da ordem pública são regulares nas decisões, sustentando-se a partir de conceitos superficiais, que a liberdade do acusado/flagrado caracteriza risco à ordem pública. Conforme se expõe: "a vida criminal do flagrado evidencia o risco de que em liberdade volte a delinquir, impondo-se a custódia para manter a ordem pública"28.

A reiteração da conduta delituosa autoriza e os elementos acima indicados revelam a importância da manutenção da segregação, haja a necessidade de se garantir a ordem pública, pois a vida criminal dos flagrados evidencia o risco de que em liberdade voltem a delinquir, impondo-se a custódia ${ }^{29}$.

Em complemento, outro ponto marcante em algumas decisões é a utilização do aspecto doutrinário de Guilherme de Souza Nucci, que não elabora as críticas pertinentes e indispensáveis para definição de reiteração criminosa como gravame à ordem pública: "a reiteração na prática criminosa é motivo suficiente para constituir gravame à ordem pública, justificador da decretação da prisão preventiva"30.

Portanto, é notória a confusão acerca da verdadeira função jurisdicional, forma de atuação que deve ser exercida pelos magistrados, pois, discursos e argumentos são embasados na concepção ilusória de que, por meio da pena de prisão, seria possível combater a continuidade delitiva ou aumento da criminalidade.

28 BRASIL. Plantão Forense da Comarca de Passo Fundo. Processo n. ${ }^{\circ}$ 021/2.18.0001623-8. 2018 (b).

29 BRASIL. Plantão Forense da Comarca de Passo Fundo. Processo n. : 021/2.18.0001587-8. 2018 (c).

30 BRASIL. Plantão Forense da Comarca de Passo Fundo. Processo n. ${ }^{\circ}$ : 021/2.18.0002357-9. 2018 (d). 
DIAS, Felipe da Veiga; SANTOS, Lucas da Silva. A prisão preventiva em Passo Fundo-RS: análise empírico-criminológica com base nas prisões decretadas em regime de plantão no ano de 2018. Revista Eletrônica Direito e Política, Programa de Pós-Graduação Stricto Sensu em Ciência Jurídica da UNIVALI, Itajaí, v.13, n.3, 30 quadrimestre de 2018. Disponível em: www.univali.br/direitoepolitica - ISSN 1980-7791

Todavia, a frequência de discursos como: "ainda, a probabilidade de o representado voltar a delinquir, bem como a sensação de insegurança que a pronta liberdade do delinquente gera na comunidade, agrava sobremaneira a ordem pública, que deve ser restabelecida" ${ }^{31}$.Verificam-se discursos tendenciosos que partem de sofismas (como o "perigo de reiteração") ${ }^{32}$, visto que corroboram a propagação do senso comum punitivo, pois visam consumar o controle social através do cárcere.

Nessa linha, observam-se decisões judiciais que apresentam em suas fundamentações o empenho de tentar impossibilitar novas práticas delituosas ou impedir a continuidade delitiva, fundadas em ilações, inexistindo suporte fático ou probatório, apenas apresentando uma atuação repressiva e estratégica de controle social, e anunciando que a responsabilidade desses julgadores não está alinhada às garantias constitucionais.

Essa espécie de julgador apropria-se de uma ideologia "disfarçada", fundada na lógica da defesa social, reivindicando menos impunidade e máximo rigor penal, proveniente de uma cultura autoritária. É aquele julgador que vislumbra o discurso de "limpeza social" e, desse modo, atua inserindo-se na obrigação de proteção da lei e da ordem, como um efetivo defensor da segurança pública, em um tipo de atuação que representa uma das maiores ameaças ao processo penal democrático ${ }^{33}$.

Em síntese, discursos como: "a necessidade da conversão da prisão em flagrante em custódia preventiva, de modo a impedir a constante repetição de atos nocivos ao direito alheio, que trazem intranquilidade e temor à população"34. Apresentam-se argumentos incompatíveis com a natureza cautelar da prisão preventiva, isto é, são utilizados como mecanismos que visam antecipar a punição/castigo, ou seja, mitigando direitos e garantias fundamentais, buscando assegurar uma ilusória sensação de segurança e tranquilidade para população. Esse discurso emocional oculta o fracasso do sistema penal em cumprir com as suas promessas ${ }^{35}$.

Ademais, os discursos onde se podem revelar com facilidade argumentos para expansão punitiva, sob uma lógica de combate à impunidade, justificam-se com os melhores

31 BRASIL. Plantão Forense da Comarca de Passo Fundo. Processo n. ${ }^{\circ}$ 021/2.18.0002356-0. 2018 (e).

32 LOPES JÚNIOR, Aury. Direito Processual Penal. 11 ed. São Paulo: Saraiva, 2014. p. 619.

33 LOPES JÚNIOR, Aury. Direito Processual Penal. p. 112.

34 BRASIL. Plantão Forense da Comarca de Passo Fundo. Processo n. ${ }^{\circ}$ 021/2.18.0002357-9. 2018 (d).

35 KARAM, Maria Lúcia. Legislações proibicionistas em matéria de drogas e danos aos Direitos Fundamentais. Revista Verve, São Paulo, n.12, pp. 181-212, 2007, p. 189. 
DIAS, Felipe da Veiga; SANTOS, Lucas da Silva. A prisão preventiva em Passo Fundo-RS: análise empírico-criminológica com base nas prisões decretadas em regime de plantão no ano de 2018. Revista Eletrônica Direito e Política, Programa de Pós-Graduação Stricto Sensu em Ciência Jurídica da UNIVALI, Itajaí, v.13, n.3, 30 quadrimestre de 2018. Disponível em: www.univali.br/direitoepolitica - ISSN 1980-7791

objetivos, como segurança e diminuição de criminalidade. Logo, confirma-se uma atuação do judiciário que se distancia da sua função precípua de agir contramajoritariamente na defesa dos princípios e garantias constitucionais, porquanto 0 que se verifica é uma atuação pautada ao atendimento da opinião pública e aos supostos interesses da sociedade

Com tais discursos visa-se legitimar a imposição de um sistema penal repressivo. Com efeito, tais falas difundem uma lógica de defesa social, partindo do saber oficial, buscando assegurar e defender as funções utilitárias atribuídas à pena, de proteção de bens jurídicos através da intimidação ${ }^{36}$. Demonstra-se assim a fragilidade contida na eficácia invertida, pois o sistema penal é não é capaz de cumprir com "as funções que legitimam sua existência", como no caso do combate e prevenção da criminalidade por meio da pena. "E não pode cumpri-las porque sua função real não é o 'combate', mas, inversamente, a 'construção' (seletiva) da criminalidade ${ }^{37}$.

Consequentemente, o sistema penal não cumpre nenhuma de suas funções ou promessas oficialmente declaradas, excetuando a de punir. Sua verdadeira função não é intimidar possíveis novas práticas criminosas ou ressocializar os réus através do cárcere, mas construir e reproduzir desigualdades escolhendo uma criminalidade particular, pautada basicamente nos crimes patrimoniais e outras práticas nominadas como crimes de rua.

Destarte, a garantia da ordem pública como fundamento da prisão preventiva evidencia que verdadeiramente a prisão preventiva está cumprindo com as "funções reais" (prevenção geral e especial) de antecipação da pena, assim, acentuando sua discrepância com a natureza cautelar. Conforme aduz Lopes Júnior, "em suma, as prisões para garantia da ordem pública ou da ordem econômica possuem um defeito genético: não são cautelares. Portanto, substancialmente inconstitucionais"38.

Posto isso, a sistemática instrumentalização da prisão preventiva, selecionada para determinados acusados/imputados, assevera a finalidade estatal de buscar respostas instantâneas às demandas punitivas da população, por meio da adequação do processo

\footnotetext{
${ }^{36}$ ANDRADE, Vera Regina Pereira de. A ilusão da segurança jurídica: do controle da violência à violência do controle penal. Porto Alegre: Livraria do Advogado, 2003. p. 181-183.

37 ANDRADE, Vera Regina Pereira de. Pelas mãos da criminologia: o controle penal para além da (des)ilusão. p. 280.

38 LOPES JÚNIOR, Aury. Direito Processual Penal. p. 618.
} 
DIAS, Felipe da Veiga; SANTOS, Lucas da Silva. A prisão preventiva em Passo Fundo-RS: análise empírico-criminológica com base nas prisões decretadas em regime de plantão no ano de 2018. Revista Eletrônica Direito e Política, Programa de Pós-Graduação Stricto Sensu em Ciência Jurídica da UNIVALI, Itajaí, v.13, n.3, 30 quadrimestre de 2018. Disponível em: www.univali.br/direitoepolitica - ISSN 1980-7791

cautelar como mecanismo que visa assegurar os anseios por segurança pública, em especial, aqui, com base na garantia da ordem pública.

\subsection{A REINCIDÊnCIA OU PRIMARIEDADE DOS RÉUS POSSUEM A MESMA RELEVÂNCIA?}

Outro ponto analisado nas decisões são os discursos que explanam, sejam explicitamente ou implicitamente, referências acerca da reincidência e maus antecedentes acostados pelos réus. Diante disso, busca-se averiguar tais aspectos no momento da fundamentação da prisão preventiva, no sentido de averiguar se a reincidência ou primariedade, maus antecedentes ou bons antecedentes possuem a mesma relevância nos discursos fundamentadores.

Verifica-se, majoritariamente, a partir dos decretos prisionais preventivos consubstanciados no estudo, que é reservado nas decisões um momento no qual os juízes analisam a possibilidade da reincidência ou maus antecedentes ostentados pelos réus. Nota-se que os juízes se debruçam de forma extensa na maioria das decisões, argumentando a partir de uma lógica binária, primariedade ou reincidência e, partindo dessa lógica (dogmática), trazendo suposições, ilações de continuidade delitiva dos réus reincidentes ou que possuem maus antecedentes (projeções futuras).

Isso pode ser visto no trecho que diz respeito à conduta social de um dos réus em sentido negativo, de modo que: "as condenações sofridas não se apresentaram suficientes para impedir a prática de novos fatos, podendo se concluir que, se solto, 0 representado poderá continuar a reincidir na conduta criminosa"39.

Nesse sentindo, embasados nas certidões de antecedentes criminais, os juízes visam demonstrar a necessidade da imediata segregação dos réus, sob a justificativa da prevenção de novas práticas criminosas, pois as condenações anteriormente sofridas (por responder em outro processo criminal) não tiveram o condão de impedir as novas ou supostas ocorrências delituosas.

Os discursos dos juízes são bastante similares acerca da reincidência ou maus antecedentes acostados pelos réus, que como regra são apresentados de forma rápida e superficial. A partir das condenações já sofridas pelos réus (ressalvando que não foram suficientes), busca-se justificar a segregação da liberdade para, desse modo, impedir novos ilícitos.

39 BRASIL. Plantão Forense da Comarca de Passo Fundo. Processo n. ${ }^{\circ}$ : 021/2.18.0001206-2. 2018 (f). 
DIAS, Felipe da Veiga; SANTOS, Lucas da Silva. A prisão preventiva em Passo Fundo-RS: análise empírico-criminológica com base nas prisões decretadas em regime de plantão no ano de 2018. Revista Eletrônica Direito e Política, Programa de Pós-Graduação Stricto Sensu em Ciência Jurídica da UNIVALI, Itajaí, v.13, n.3, 30 quadrimestre de 2018. Disponível em: www.univali.br/direitoepolitica - ISSN 1980-7791

O crime cometido é grave, e a ousadia em praticar o fato em plena luz do dia causa espanto, ainda, embora de fato a criminalidade venha crescendo de modo vertiginoso em nossa Comarca, não mais se limitando ao período noturno. O fato de já ter sido condenado, com penas altas e recentes, ainda em cumprimento, demonstra o risco à sociedade em manter o agente em liberdade, face à reiteração $\operatorname{criminosa}^{40}$.

Nesse outro discurso acima exemplificado, o magistrado traz em sua decisão perspectivas que não são inerentes a sua função jurisdicional, ou seja, um "ponto de vista pessoal", de certo modo desabafando acerca da ousadia do réu ao praticar o delito durante a luz do dia e o aumento vertiginoso da criminalidade na comarca. Trata-se de "falas" que não possuem relevância nenhuma, sequer justifica-se estarem presentes na decisão, que deveria estar fundamentada juridicamente e não a partir de uma perspectiva pessoal (discricionária e subjetiva) ${ }^{41}$.

Novamente verifica-se a confusão realizada pelos magistrados acerca de suas funções, pois o combate à criminalidade não é função pertencente ao Judiciário. É preocupante discursos de julgadores que se revelam comprometidos com o combate à criminalidade, atuando como guardiões da segurança púbica ao invés de garantidores dos direitos e garantias fundamentais.

Contudo, verifica-se que a importância conferida à reincidência dos réus difere nas decisões quando se trata da primariedade. Em sentido contrário apresentam-se justificativas para demonstrar que ainda que os réus sejam primários, ostentam maus antecedentes, pois respondem por fato idêntico ou diverso e, se ficarem em liberdade, continuarão a "delinquir".

O flagrado Isaac assumiu ser o proprietário da arma apreendida. Conforme se verifica da certidão acostada aos autos, não ostenta condenações, porém, responde a processo de crime contra o patrimônio. Tal situação, demonstra que sua conduta social é negativa e reprovável, podendo-se concluir que, se solto, poderá continuar a reincidir na conduta criminosa ${ }^{42}$.

A argumentação acima reflete claramente a vasta gama de alternativas disponíveis para justificar/fundamentar os decretos das prisões preventivas. Deste modo, em determinada

40 BRASIL. Plantão Forense da Comarca de Passo Fundo. Processo n. ${ }^{\circ}$ : 021/2.18.0002574-1. 2018 (g).

41 STRECK, Lenio Luiz. O que é isto - decido conforme minha consciência. 2 ed. Porto Alegre: Livraria do Advogado, 2010. p. 87.

42 BRASIL. Plantão Forense da Comarca de Passo Fundo. Processo n. ${ }^{\circ}$ : 021/2.18.0000142-7. 2018 (h). 
DIAS, Felipe da Veiga; SANTOS, Lucas da Silva. A prisão preventiva em Passo Fundo-RS: análise empírico-criminológica com base nas prisões decretadas em regime de plantão no ano de 2018. Revista Eletrônica Direito e Política, Programa de Pós-Graduação Stricto Sensu em Ciência Jurídica da UNIVALI, Itajaí, v.13, n.3, 30 quadrimestre de 2018. Disponível em: www.univali.br/direitoepolitica - ISSN 1980-7791

decisão, é imprescindível a circunstância do acusado/réu ser reincidente, todavia, em outra decisão, a primariedade não possui tanta importância, não sendo fundamento determinante para garantir que os acusados/réus respondam seus processos em liberdade.

Outro caso apreciado apresenta o acusado que possui dezoito anos recém-completos (frisado na decisão), mas não possui nenhuma condenação ou maus antecedentes. No entanto, busca-se justificar a prisão preventiva pelos antecedentes infracionais: "analisando a certidão de antecedentes criminais, verifico que o representado A. M. S. não possui antecedentes criminais. Entretanto, consta nos autos os antecedentes policiais infracionais do representado" 43 .

Nesse sentindo, é perceptível que embora conhecida a separação entre a jurisdição penal e a reservada para apuração dos atos infracionais praticados por crianças e adolescentes, tal distinção acaba por ser relativizada (quando conveniente). Revela-se, pois, uma clara tentativa de buscar instrumentos que comprovem que o acusado é perigoso, ainda que os atos infracionais não possam ser reconhecidos como maus antecedentes.

Por fim, os argumentos e justificativas apresentados no tocante à reincidência e maus antecedentes dos réus expõem pontos em comum nas decisões analisadas, pois são construídas de forma extremamente subjetiva. Logo, fica evidente a discricionariedade e a variação de relevância de tais aspectos nos decretos prisionais preventivos.

\subsection{FUMUS COMMISSI DELICTI E PERICULUM LIBERTATIS NOS DECRETOS PRISIONAIS PREVENTIVOS}

De acordo com o artigo 312 do Código de Processo Penal: "a prisão preventiva poderá ser decretada como garantia da ordem pública, da ordem econômica, por conveniência da instrução criminal, ou para assegurar a aplicação da lei penal, quando houver prova da existência do crime e indício suficiente de autoria"44.

Segundo a definição de Badaró, "fumus commissi delicti consistente na prova da existência do crime e indício suficiente de autoria, aliado à pelo menos uma das hipóteses de periculum libertatis do mesmo dispositivo"45. Nesse sentindo, Lopes Júnior

43 BRASIL. Plantão Forense da Comarca de Passo Fundo. Processo n. ${ }^{\circ}$ : 021/2.18.0002392-7. 2018 (i).

44 BRASIL. Código de Processo Penal. Decreto Lei n³.689, de 03 de outubro de 1941. 971.

45 BADARÓ, Gustavo Henrique. Processo Penal. 3. ed. São Paulo: Revista dos Tribunais, 2015. p. 
DIAS, Felipe da Veiga; SANTOS, Lucas da Silva. A prisão preventiva em Passo Fundo-RS: análise empírico-criminológica com base nas prisões decretadas em regime de plantão no ano de 2018. Revista Eletrônica Direito e Política, Programa de Pós-Graduação Stricto Sensu em Ciência Jurídica da UNIVALI, Itajaí, v.13, n.3, 30 quadrimestre de 2018. Disponível em: www.univali.br/direitoepolitica - ISSN 1980-7791

preceitua periculum libertatis como "o perigo que decorre do estado de liberdade do sujeito passivo, previsto no Código de Processo Penal como o risco para a ordem pública, ordem econômica, conveniência da instrução criminal ou para assegurar a aplicação da lei penal"46.

Dito isso, passa-se à análise da presença desses requisitos e fundamentos nas decisões consubstanciadas no estudo. Consegue-se identificar que, de modo bastante superficial, os magistrados utilizam-se das expressões fumus comissi delicti e periculum libertatis, apenas retratando a existência dos requisitos, combinando-as com a citação dos artigos do Código de Processo Penal. Conforme trechos: "Nesse cenário, presente está o fummus comissi delicti na forma do art. 312/Código de Processo Penal"47.

Em juízo normativo das hipóteses do artigo 312 do Código de Processo Penal, ultrapassada, já análise do flagrante, a análise da existência de indicativos da materialidade do fato e da autoria, constata-se que, por enquanto, configura-se o periculum libertatis, em virtude do risco à ordem pública e à aplicação da lei penal ${ }^{48}$.

Com fulcro nesse contexto, verifica-se nos discursos acima citados, além da sua repetição em outras decisões, que os magistrados citam a presença do fumus comissi delicti e periculum libertatis, mas de forma genérica. Em síntese, não apresentam um juízo de probabilidade com base na situação fática e probatória concreta trazida nos autos, ou seja, "exigem um suporte em motivos de fato, em circunstâncias atuais e concretas, capazes de atender aos requisitos autorizadores. Meras possibilidades afastam os requisitos legais, na medida em que são os fatos concretos que motivam as medidas cautelares" 49 .

Conforme o artigo 315 do Código de Processo Penal, "a decisão que decretar, substituir ou denegar a prisão preventiva será sempre motivada"50. Entretanto, reiteradamente se observam projeções e conjecturas dos magistrados para a decretação da prisão preventiva. Essa postura não é compatível com o instituto; a prisão preventiva não pode ser decretada com a mera transcrição ou simples menção de seus requisitos legais, aliás,

\footnotetext{
46 LOPES JÚNIOR, Aury. Direito Processual Penal. p. 607.

47 BRASIL. Plantão Forense da Comarca de Passo Fundo. Processo n. ${ }^{\circ}$ 021/2.18.0002356-0. 2018 (e).

48 BRASIL. Plantão Forense da Comarca de Passo Fundo. Processo n. ${ }^{\circ}$ 021/2.18.0001460-0. $2018(j)$.
}

49 GIACOMOLLI, Nereu José. Prisão, liberdade e as cautelares alternativas ao cárcere. São Paulo: Marcia Pons, 2013. p. 17.

50 BRASIL. Código de Processo Penal. Decreto Lei n³.689, de 03 de outubro de 1941. 
DIAS, Felipe da Veiga; SANTOS, Lucas da Silva. A prisão preventiva em Passo Fundo-RS: análise empírico-criminológica com base nas prisões decretadas em regime de plantão no ano de 2018. Revista Eletrônica Direito e Política, Programa de Pós-Graduação Stricto Sensu em Ciência Jurídica da UNIVALI, Itajaí, v.13, n.3, 30 quadrimestre de 2018. Disponível em: www.univali.br/direitoepolitica - ISSN 1980-7791

a medida excepcionalíssima não pode ser embasada em suposições de autoria do crime ou perigo abstrato da liberdade do acusado.

A reprodução única ou simplesmente dos dispositivos da legislação processual penal, assim como a transcrição de parecer do Ministério Público ou relatório da Autoridade Policial, não podem ser considerados como fundamentação de um decreto prisional preventivo, pois a decisão deve estar fundamentada e motivada partindo da presença dos suportes fáticos e probatórios do caso concreto ${ }^{51}$.

Portanto, exige-se um juízo sério de caso a caso, visto que a liberdade é regra. Posto isso, elementos genéricos sem relação fática não podem ser considerados para a segregação do acusado, de modo que "o perigo gerado pelo estado de liberdade do imputado deve ser real, com um suporte fático e probatório suficiente para legitimar tão gravosa medida"52.

Por fim, conforme exposto, as decisões mencionam hipóteses vazias ou com parcas fundamentações/motivações, baseadas em meras projeções sobre o perigo da manutenção da liberdade do réu. Logo, afastam a natureza cautelar da prisão preventiva, alicerçados em uma suposta Defesa Social amparada no caráter vago dos termos dispostos na norma cautelar processual que simplificam o cerceamento da liberdade.

\subsection{AS MEDIDAS CAUTELARES DIVERSAS DA PRISÃO POSSÍVEIS ALTERNATIVAS AO ENCARCERAMENTO?}

As medidas cautelares diversas da prisão estão previstas no artigo 319 do Código de Processo Penal ${ }^{53}$ o qual, após a reforma legislativa parcial no ano de 2011, buscou alternativas na tentativa de redução das penas de encarceramento impostas pelo Judiciário em âmbito nacional. Segundo o art. 282, § $6^{\circ}$ do Código de Processo Penal: "a prisão preventiva será determinada quando não for cabível a sua substituição por outra medida cautelar"54.

Todavia, apesar da reforma legislativa, o anuário estatístico da Justiça Criminal produzido pelo Conselho Nacional de Justiça confirma a baixa adesão da magistratura nacional às

\footnotetext{
${ }^{51}$ GIACOMOLLI, Nereu José. Prisão, liberdade e as cautelares alternativas ao cárcere. p. 16-17.

52 LOPES JÚNIOR, Aury. Prisões Cautelares. p. 101.

53 BRASIL. Código de Processo Penal. Decreto Lei n³.689, de 03 de outubro de 1941.

${ }^{54}$ BRASIL. Código de Processo Penal. Decreto Lei n³.689, de 03 de outubro de 1941.
} 
DIAS, Felipe da Veiga; SANTOS, Lucas da Silva. A prisão preventiva em Passo Fundo-RS: análise empírico-criminológica com base nas prisões decretadas em regime de plantão no ano de 2018. Revista Eletrônica Direito e Política, Programa de Pós-Graduação Stricto Sensu em Ciência Jurídica da UNIVALI, Itajaí, v.13, n.3, 30 quadrimestre de 2018. Disponível em: www.univali.br/direitoepolitica - ISSN 1980-7791

medidas alternativas diversas da prisão; no ano de 2015 as execuções não privativas de liberdade representaram apenas $37,1 \%$ de todas as penas aplicadas no país ${ }^{55}$.

Diante do quadro apresentado, o crescimento sucessivo das penas de encarceramento corrobora a postura do Judiciário brasileiro, formado majoritariamente por julgadores que incorporam uma cultura punitivista, ou seja, não visam alternativas para o superencarceramento em massa.

Portanto, no momento da aplicação das medidas cautelares o juiz deve optar pelo meio menos gravoso, entre os diversos aptos a realizar a finalidade pretendida. Assim, sendo necessário tal medida, busca-se a que menos relativize o direito de liberdade do acusado/investigado, sendo a prisão preventiva a última medida56.

Não obstante, quando o julgador decreta a prisão preventiva para, posteriormente, verificar a adequação e a necessidade das penas alternativas a prisão, isto é, utiliza-se de forma inversa do cárcere como prima ratio, demonstra uma atuação em clara oposição as disposições previstas em Tratados internacionais de Direitos Humanos, Constituição Federal e demais Leis ordinárias ${ }^{57}$.

Nota-se, a partir da análise, que estando presentes os requisitos objetivos e subjetivos, por exemplo, a punição de crime doloso com pena em abstrato superior a quatro anos ou a reincidência em crime doloso, as medidas cautelares diversas da prisão são afastadas, pois os requisitos estão implementados. Todavia, em grande parte das decisões, as penas alternativas à prisão nem sequer são citadas.

Deste modo, conforme narrado acima: "portanto, uma vez implementados os requisitos objetivo e subjetivo e, ainda, revelando-se ineficazes as imposições de medidas cautelares diversas da prisão, a conversão da prisão em flagrante em preventiva é medida imperativa"58.

55 BRASIL. Conselho Nacional de Justiça. Estatísticas revelam aumento das condenações de encarceramento - 2016. Disponível em: <http://www.cnj.jus.br/noticias/cnj/83669-estatisticas-revelamaumento-das-condenacoes-de-encarceramento>. Acesso em 25 de mar. de 2018.

56 BADARÓ, Gustavo Henrique. Processo Penal. p. 954.

57 GIACOMOLLI, Nereu José; MAYA, André Machado. As medidas cautelares alternativas à prisão: o projeto de reforma do código de processo penal brasileiro e a realidade latino-americana. Revista Duc In Altum Cadernos de Direito, vol. 8, n. 14, pp. 177-217, jan./abr, 2016, p. 180-181. (h).

58 BRASIL. Plantão Forense da Comarca de Passo Fundo. Processo n. ${ }^{\circ}$ : 021/2.18.0000142-7. 2018 
DIAS, Felipe da Veiga; SANTOS, Lucas da Silva. A prisão preventiva em Passo Fundo-RS: análise empírico-criminológica com base nas prisões decretadas em regime de plantão no ano de 2018. Revista Eletrônica Direito e Política, Programa de Pós-Graduação Stricto Sensu em Ciência Jurídica da UNIVALI, Itajaí, v.13, n.3, 30 quadrimestre de 2018. Disponível em: www.univali.br/direitoepolitica - ISSN 1980-7791

Em outra decisão o juiz apresenta a possibilidade do deferimento da medida cautelar diversa da prisão, ou seja, estão presentes os requisitos, no entanto, busca-se justificativas para afastar a medida.

Sobre as medidas cautelares diversas da prisão, é possível que, brevemente, seja possível a substituição por cautelares diversas, especialmente depois de comprovada a residência fixa, com ânimo de definitividade, e realizadas as citações nos processos que se encontram suspensos. Por enquanto, todavia, detectado 0 nomadismo do flagrado, nenhuma das cautelares se revela suficiente para a garantia da aplicação da lei penal ${ }^{59}$.

Apenas como adendo, a não utilização das medidas cautelares diversas da prisão pela magistratura nacional confirma a ausência da ruptura da racionalidade que se direciona ao cárcere e suas perspectivas. Destarte, as penas alternativas não produzem efeitos nas taxas de encarceramento, pois o perfil do indivíduo submetido à pena restritiva de direito, considerando o tipo do delito em regra praticado, difere da "clientela" selecionada pelo sistema penal para compor a população carcerária60.

Outro discurso para compreensão: "as circunstâncias do caso concreto e o histórico do acusado indicam que as medidas cautelares diversas da prisão não são suficientes para resguardar a garantia da ordem pública, de forma que a única medida suficiente é a prisão preventiva"61.

Diante do exposto, surge a dúvida de como os juízes afirmam a ineficácia ou insuficiência de algo nunca anteriormente aplicado, ou no mínimo com tão simplória alusão e sem nenhuma justificação aparentemente plausível. A partir dos discursos, fica perceptível a opção discricionária dos juízes sobre dispositivos da legislação penal e processual penal.

Contrariando a observância sistemática das disposições elencadas nos artigos $282, \varsigma^{\circ}$ e 319 do Código de Processo Penal62, observa-se nitidamente a utilização seletiva dos dispositivos quando presentes os requisitos necessários para a não aplicação das penas

59 BRASIL. Plantão Forense da Comarca de Passo Fundo. Processo n. : 021/2.18.0001460-0. 2018 (j).

60 SOUZA, Guilherme Augusto Dornelles de; AZEVEDO, Rodrigo Ghiringhelli de. Analisar alternativas à prisão: proposta para superar uma dicotomia. O público e o privado. Ceará, n. 26, pp. 115-138, jul./dez., 2015, p. 119-121.

${ }^{61}$ BRASIL. Plantão Forense da Comarca de Passo Fundo. Processo n. : 021/2.18.0002392-7. 2018 (i).

62 BRASIL. Código de Processo Penal. Decreto Lei n³.689, de 03 de outubro de 1941. 
DIAS, Felipe da Veiga; SANTOS, Lucas da Silva. A prisão preventiva em Passo Fundo-RS: análise empírico-criminológica com base nas prisões decretadas em regime de plantão no ano de 2018. Revista Eletrônica Direito e Política, Programa de Pós-Graduação Stricto Sensu em Ciência Jurídica da UNIVALI, Itajaí, v.13, n.3, 30 quadrimestre de 2018. Disponível em: www.univali.br/direitoepolitica - ISSN 1980-7791

alternativas à prisão, sendo esses dispositivos ignorados ou relativizados quando recomendariam a aplicação de tais medidas ${ }^{63}$.

Assim, as decisões que mencionam as medidas não demonstram explicações precisas, ou seja, as razões, motivos concretos que justificam a não aplicação das medidas cautelares diversas da prisão. Ainda, percebe-se que quando praticável a aplicação de uma medida menos gravosa que não restrinja os direitos e liberdades inerentes ao acusado, acaba-se por apresentar justificações para a sua não aplicação.

Novamente, evidenciam-se nas decisões projeções futurísticas ao declarar-se a ineficiência de uma medida nunca imposta naquele caso concreto. Nesse contexto de adivinhação, "como provar que amanhã, se permanecer solto, não cometerei um crime? uma prova impossível de ser feita, tão impossível como a afirmação de que amanhã eu o praticarei. Trata-se de recusar o papel de juízes videntes"64.

Por fim, percebem-se preconcepções distorcidas intimamente ligadas à prisão cautelar, principalmente, quando julgadores acreditam no sistema de justiça criminal (em especial através da privação da liberdade) como mecanismo para diminuição da criminalidade. Deste modo, direitos e garantias fundamentais são postos como obstáculos à segurança pública. Verificam-se discursos dirigidos e construídos sob a lógica do espetáculo (sempre em nome da luta do bem e do mal), que visam legitimar prisões desnecessárias, para agradar às maiorias de ocasião65.

\subsection{A PRISÃo PREVENTIVA (SITUACIONAL) OU ANTECIPAÇÃo DO CUMPRIMENTO DA PENA?}

A prisão preventiva é uma medida excepcional. Possui por isso um caráter de provisionalidade, na medida que deve ser priorizada sempre a via menos gravosa e que cause menor limitação ao direito de liberdade do réu. Outrossim, quando desaparecida a estrutura fática legitimadora às "fumaças" (fumus commissi delicti e periculum libertatis), deve-se findar a prisão preventiva imediatamente ${ }^{66}$.

\footnotetext{
63 LOPES JÚNIOR, Aury. Prisões Cautelares. p. 154.

64 LOPES JÚNIOR, Aury. Direito Processual Penal. p. 619.

65 CASARA, Rubens. A ampliação das hipóteses da prisão preventiva: uma corrupção das conquistas civilizatórias. Boletim do Instituto Brasileiro de Ciências Criminais. São Paulo, boletim n. 277, p. 21-22, dez. 2015, p. 12-13.

${ }^{66}$ BADARÓ, Gustavo Henrique. Processo Penal. p. 960. e LOPES JÚNIOR, Aury. Direito Processual Penal. p. 578.
} 
DIAS, Felipe da Veiga; SANTOS, Lucas da Silva. A prisão preventiva em Passo Fundo-RS: análise empírico-criminológica com base nas prisões decretadas em regime de plantão no ano de 2018. Revista Eletrônica Direito e Política, Programa de Pós-Graduação Stricto Sensu em Ciência Jurídica da UNIVALI, Itajaí, v.13, n.3, 30 quadrimestre de 2018. Disponível em: www.univali.br/direitoepolitica - ISSN 1980-7791

Os (16) dezesseis processos consubstanciados no estudo, conforme já exposto anteriormente a respeito das naturezas (tipos) dos crimes imputados/praticados pelos réus, estão divididos em: Roubo (08), Furto (4), Produção e Tráfico Ilícito de Drogas (1), Receptação (2), Porte ilegal de arma (1).

A partir disso, no dia $1^{\circ}$ de julho de 2018 , foram consultadas as situações processuais no site do Tribunal de Justiça do Estado do Rio Grande do Sul, em "acompanhamento processual", "ver todas as movimentações", com objetivo de verificar em quais processos os réus continuavam presos preventivamente, ou em quais processos foram revogadas as respectivas prisões preventivas. Além disso, verificou-se o tempo médio das prisões preventivas na comarca, considerando o dia em que foi decretada a prisão e o $1^{\circ}$ dia do mês de julho (data em que foi realizada a consulta).

Nesse ponto cabe um adendo, já que nas consultas realizadas em $1^{\circ}$ de julho de 2018 com o objetivo de verificar a duração (tempo) das prisões preventivas foi constatado que em quatro situações processuais ocorreu a alteração de sua tramitação, ou seja, decisões que não tramitavam em segredo de justiça entre os meses de janeiro a março, mas, que passaram a tramitar em sigilo. Deste modo, embora possuindo decisões que decretaram as prisões preventivas (tendo em vista na época em que foi proferida a decisão não se tratar de segredo de justiça), cerca de quatro decisões não foram utilizadas nesse trabalho no momento da análise discursiva dos juízes, isto é, foram colhidas apenas informações gerais e quantitativas dos réus como: idade, sexo, raça/cor, natureza do crime imputado/praticado, se primário, se reincidente, não analisando os fundamentos e discursos proferidos pelos magistrados para decretação das prisões preventivas.

O tempo de duração das prisões preventivas está calculado entre a data da decretação até a data final de 01.07.2018 (dia em que foi realizada a consulta), distribuída em ordem decrescente, do maior tempo para o menor: $1^{\circ}: 173$ dias; $2^{\circ}: 152$ dias; $3^{\circ}: 149$ dias; $4^{\circ}: 145$ dias; 5०: 143 dias; 60: 142 dias; 70: 121 dias; $8^{\circ}: 114$ dias; $9^{\circ}: 114$ dias; 10०: 109 dias; $11^{\circ}$ : 93 dias, data final nesse caso foi em 23.05.2018 (data em que foi revogada a prisão preventiva); $12^{\circ}: 34$ dias, data final nesse caso foi em 04.04.2018 (data em que foi revogada a prisão preventiva).

Resta claro que o tempo em dias das prisões preventivas pode aumentar, pois o critério utilizado foi a data "final" 01.07.2018. A maioria dos casos foram prisões em flagrante convertidas em prisão preventiva, logo, a data do decreto prisional preventivo já se leva em consideração para iniciar a contagem. Nas doze situações chegou-se ao total de 1.489 dias de prisões sem condenação, o que dá uma média de 124 dias por processo, 
DIAS, Felipe da Veiga; SANTOS, Lucas da Silva. A prisão preventiva em Passo Fundo-RS: análise empírico-criminológica com base nas prisões decretadas em regime de plantão no ano de 2018. Revista Eletrônica Direito e Política, Programa de Pós-Graduação Stricto Sensu em Ciência Jurídica da UNIVALI, Itajaí, v.13, n.3, 30 quadrimestre de 2018. Disponível em: www.univali.br/direitoepolitica - ISSN 1980-7791

mais de 04 meses. Cabem dois questionamentos a partir dessas constatações: será que nos casos em que foi realizado o presente estudo, realmente são situações para utilização da prisão preventiva? Estavam presentes em todas as situações o periculum libertatis?

Conforme aduz Lopes Júnior, o periculum libertatis deve estar presente (não passado ou futuro hipotético). É preciso um juízo sério acerca da atualidade do perigo do réu, com suporte nas provas constantes nos autos. Destaca-se que a prisão não é apenas considerada excessiva pela sua duração, porém conjuntamente pela manutenção da custódia depois de findar-se as razões que a legitimam ${ }^{67}$.

No entanto, identifica-se que com a atual postura do Judiciário em âmbito nacional, não é possível auferir a prisão preventiva o seu caráter de excepcionalidade, nem se cumpre considerar de caráter provisório. A média de duração da prisão provisória nacional oscila entre inicialmente 172 dias e 974 dias, ou seja, podendo prisões provisórias chegarem a mais de dois anos e seis meses de custódia sem condenação, aliados aos dados que mostram que sete estados da federação possuem uma população carcerária com mais de $54 \%$ de presos provisórios, superando a população de presos condenados. O estado do Rio Grande do Sul, possui prisões provisórias com a duração média de 437 dias $^{68}$.

Com esse panorama de banalização do uso das prisões preventivas mostra-se a incorporação do Judiciário dos desejos manifestos do senso comum punitivo, que não objetivam aguardar por um processo respeitador das regras do jogo, e sim anseiam pela imediata punição do acusado, independentemente que dessa "aceleração" da punição advenham supressões de garantias processuais, ratificando o "fascínio" pelas prisões, pois, através delas, conquista-se a concretização/viabilização da punição69

Portanto, a permanente instrumentalização da prisão preventiva, sendo eleita para determinados acusados, assevera a finalidade estatal de buscar respostas urgentes às demandas punitivas da sociedade, por meio da adequação do processo cautelar como mecanismo que visa assegurar segurança pública, não atendendo as características da medida cautelar.

\footnotetext{
67 LOPES JÚNIOR, Aury. Prisões Cautelares. p. 35.

68 BRASIL. Conselho Nacional de Justiça. Reunião Especial de Jurisdição do CNJ com os Presidentes dos Tribunais de Justiça dos Estados - 2017 (b). Disponível em: <http://www.cnj.jus.br/files/conteudo/arquivo/2017/02/b5718a7e7d6f2edee274f93861747304.pdf>. Acesso em 03 de mar. de 2018.
}

69 KHALED JÚNIOR, Salah H. A busca da verdade no processo penal: para além da ambição inquisitorial. 2 ed. Belo Horizonte. Letramento: Casa do Direito, 2016. p. 402. 
DIAS, Felipe da Veiga; SANTOS, Lucas da Silva. A prisão preventiva em Passo Fundo-RS: análise empírico-criminológica com base nas prisões decretadas em regime de plantão no ano de 2018. Revista Eletrônica Direito e Política, Programa de Pós-Graduação Stricto Sensu em Ciência Jurídica da UNIVALI, Itajaí, v.13, n.3, 30 quadrimestre de 2018. Disponível em: www.univali.br/direitoepolitica - ISSN 1980-7791

\section{CONSIDERAÇÕES FINAIS}

O debate proposto neste estudo empírico acerca da prisão preventiva e os discursos e fundamentos jurídicos utilizados pelos juízes e juízas para decretação da medida cautelar excepcionalíssima busca, a partir dos dados particulares encontrados, compreender a atuação jurisdicional local em sentido estrito.

Assim, ao comparar o plano regional no qual se situa o objeto de pesquisa ao plano nacional, no tocante ao uso banalizado das prisões preventivas, tal estudo propicia a constatação de algumas situações. Primeiramente, a presença de discursos proferidos pelos juízes evidencia uma confusão acerca de suas reais funções e formas de atuações, visto que atuam atrelados a uma ideologia de defesa social, inclusive, relativizando direitos e garantias fundamentais em favor das pautas de segurança.

Nessa esteira, ainda utilizam a prisão preventiva como instrumento de antecipação da punição, visando produzir respostas instantâneas para a opinião pública e sociedade. Destarte, agem como agentes de segurança pública, apenas ratificando uma atuação repressiva e estratégica de controle social.

A fundamentação jurídica dos magistrados da comarca se assemelha em diversos pontos, principalmente ao decretar a prisão preventiva para garantia da ordem pública. Ademais, as decisões trazem em suas fundamentações a "tentativa" de impedir novas práticas delituosas ou impedir a continuidade delitiva, apoiadas em meras suposições, sem a presença de suportes fáticos ou probatórios.

Posto isso, a partir da observação das decisões, verifica-se que determinados discursos e fundamentos jurídicos e "não jurídicos" são repetitivos em sua grande maioria, todavia, ainda é possível conferir variação de relevância dos argumentos. Logo, ora elementos são fundamentais para decretação da prisão preventiva, ora tais elementos não são relevantes para manutenção da liberdade dos réus.

Outro ponto que cumpre destacar são as argumentações construídas com o uso de subjetivismo extremo na interpretação jurídica, isto é, discricionariedade. Em determinadas decisões proferidas pelos magistrados, a reincidência e maus antecedentes são primordiais para decretação da prisão preventiva, já em outras decisões com a mesma natureza delitiva, possivelmente praticado pelo réu, a primariedade ou bons antecedentes não possuem a mesma importância. 
DIAS, Felipe da Veiga; SANTOS, Lucas da Silva. A prisão preventiva em Passo Fundo-RS: análise empírico-criminológica com base nas prisões decretadas em regime de plantão no ano de 2018. Revista Eletrônica Direito e Política, Programa de Pós-Graduação Stricto Sensu em Ciência Jurídica da UNIVALI, Itajaí, v.13, n.3, 30 quadrimestre de 2018. Disponível em: www.univali.br/direitoepolitica - ISSN 1980-7791

Em suma, o maior problema da banalização da prisão preventiva e do superencarceramento em massa não são resultantes apenas da falta de alternativas ou de propostas capazes de reduzir tal situação calamitosa, pois apesar das alternativas/propostas que possibilitem que mecanismos efetivos possam auxiliar ao combate das superlotações dos presídios, ainda resistem nas decisões judiciais fundamentos que autorizam a seletividade (com base discricionária) do sistema penal para com os estratos sociais mais pobres.

Conclui-se que é imprescindível uma ruptura com a cultura punitiva presente no Judiciário e na sociedade, sobretudo porque a criação de leis ou alternativas desprovidas de tal ruptura não possuem a capacidade de transformar ou produzir mudanças efetivas. Outrossim, caso não aconteça essa ruptura, permanecerá a atual visão punitivista e encarceradora, que lesa não apenas o sistema prisional, mas todo e qualquer sujeito que responda a um processo penal no Brasil, algo que as decisões judiciais não vêm sendo capazes de impedir ou tampouco resistir diante dos resultados constatados na Comarca de Passo Fundo-RS.

\section{REFERÊNCIA DAS FONTES CITADAS}

AMARAL, Augusto Jobim do. Política da prova e cultura: a governabilidade inquisitiva no processo penal brasileira contemporâneo. São Paulo: Almedina, 2014.

ANDRADE, Vera Regina Pereira de. Pelas mãos da criminologia: o controle penal para além da (des)ilusão. Rio de Janeiro: Revan, 2012.

. A ilusão da segurança jurídica: do controle da violência à violência do controle penal. Porto Alegre: Livraria do Advogado, 2003.

BADARÓ, Gustavo Henrique. Processo Penal. 3. ed. São Paulo: Revista dos Tribunais, 2015.

BARATTA, Alessandro. Criminologia Crítica e Crítica do Direito Penal. Tradução: Juarez Cirino dos Santos. 3. ed. Rio de Janeiro: Revan, 2002.

BARAK, Greg. The crimes of the powerful and the globalization of crime. Revista Brasileira de Direito. v. 11, n. 2, jul-dez., 2015.

BRASIL. Código de Processo Penal. Decreto Lei n³.689, de 03 de outubro de 1941.

Disponível em: <http://www.planalto.gov.br/ccivil_03/decreto-

lei/Del3689Compilado.htm>. Acesso em: 20 de mar. de 2018.

BRASIL. Conselho Nacional de Justiça. Estatísticas revelam aumento das condenações de encarceramento - 2016. Disponível em: <http://www.cnj.jus.br/noticias/cnj/83669estatisticas-revelam-aumento-das-condenacoes-de-encarceramento>. Acesso em 25 de mar. de 2018. 
DIAS, Felipe da Veiga; SANTOS, Lucas da Silva. A prisão preventiva em Passo Fundo-RS: análise empírico-criminológica com base nas prisões decretadas em regime de plantão no ano de 2018. Revista Eletrônica Direito e Política, Programa de Pós-Graduação Stricto Sensu em Ciência Jurídica da UNIVALI, Itajaí, v.13, n.3, 30 quadrimestre de 2018. Disponível em: www.univali.br/direitoepolitica - ISSN 1980-7791

BRASIL. Levantamento Nacional de Informações Penitenciárias INFOPEN - atualização Junho de 2016. 2017 (a). Disponível em: <http://www.justica.gov.br/news/ha-726-712pessoas-presas-no-brasil/relatorio_2016_junho.pdf>. Acesso em 25 de mar. de 2018.

BRASIL. Conselho Nacional de Justiça. Reunião Especial de Jurisdição do CNJ com os Presidentes dos Tribunais de Justiça dos Estados - 2017 (b). Disponível em: <http://www.cnj.jus.br/files/conteudo/arquivo/2017/02/b5718a7e7d6f2edee274f938617 47304.pdf>. Acesso em 03 de mar. de 2018.

BRASIL. Tribunal de Justiça do Estado do Rio Grande do Sul. Comarca de Passo Fundo e municípios jurisdicionados. 2018(a). Disponível em: <https://www.tjrs.jus.br/institu/comarcas/dados_comarca.php?codigo=1312>. Acesso em 23 fev. 2018.

BRASIL. Plantão Forense da Comarca de Passo Fundo. Processo n. ${ }^{\circ}$ : 021/2.18.00016238. 2018 (b)

BRASIL. Plantão Forense da Comarca de Passo Fundo. Processo n. ${ }^{\circ}$ : 021/2.18.00015878. 2018 (c)

BRASIL. Plantão Forense da Comarca de Passo Fundo. Processo n. ${ }^{\circ}$ : 021/2.18.00023579. 2018 (d)

BRASIL. Plantão Forense da Comarca de Passo Fundo. Processo n. ${ }^{\circ}$ : 021/2.18.00023560. 2018 (e)

BRASIL. Plantão Forense da Comarca de Passo Fundo. Processo n. ${ }^{\circ}$ : 021/2.18.00012062. $2018(f)$

BRASIL. Plantão Forense da Comarca de Passo Fundo. Processo n. ${ }^{\circ}$ : 021/2.18.00025741. $2018(\mathrm{~g})$

BRASIL. Plantão Forense da Comarca de Passo Fundo. Processo n. ${ }^{\circ}$ : 021/2.18.00001427. $2018(\mathrm{~h})$

BRASIL. Plantão Forense da Comarca de Passo Fundo. Processo n. ${ }^{\circ}$ 021/2.18.00023927. 2018 (i)

BRASIL. Plantão Forense da Comarca de Passo Fundo. Processo n. ${ }^{\circ}$ : 021/2.18.00014600. $2018(\mathrm{j})$

BRASIL. Plantão Forense da Comarca de Passo Fundo. Processo n. ${ }^{\circ}$ : 021/2.18.00018974. $2018(k)$

BRASIL. Plantão Forense da Comarca de Passo Fundo. Processo n. ${ }^{\circ}$ : 021/2.18.00015134. 2018 (I)

BRASIL. Plantão Forense da Comarca de Passo Fundo. Processo n. ${ }^{\circ}$ : 021/2.18.00025750. $2018(\mathrm{~m})$

BRASIL. Conselho Nacional de Justiça. Banco Nacional de Monitoramento de Prisões -

BNMP 2.0: Cadastro Nacional de Presos. Brasília, agosto de 2018. 2018(n). Disponível em: 
DIAS, Felipe da Veiga; SANTOS, Lucas da Silva. A prisão preventiva em Passo Fundo-RS: análise empírico-criminológica com base nas prisões decretadas em regime de plantão no ano de 2018. Revista Eletrônica Direito e Política, Programa de Pós-Graduação Stricto Sensu em Ciência Jurídica da UNIVALI, Itajaí, v.13, n.3, 30 quadrimestre de 2018. Disponível em: www.univali.br/direitoepolitica - ISSN 1980-7791

<http://www.cnj.jus.br/files/conteudo/arquivo/2018/08/987409aa856db291197e81ed31 4499fb.pdf>. Acesso em 12 ago. 2018.

BUDÓ, Marília de Nardin. Mídias e discursos do poder: a legitimação discursiva do processo de encarceramento da juventude pobre no Brasil. Tese (Doutorado em Direito) - Curso de Pós-Graduação em Direito, Universidade Federal do Paraná, Curitiba, 2013.

CARNEIRO, Sueli. Racismo, sexismo e desigualdade no Brasil. São Paulo: Selo Negro, 2011.

CARVALHO, Salo de. O encarceramento seletivo da juventude negra brasileira: a decisiva contribuição do Poder Judiciário. Revista da Faculdade de Direito UFMG. Belo Horizonte, n. 67, jul.-dez. 2015.

CASARA, Rubens. A ampliação das hipóteses da prisão preventiva: uma corrupção das conquistas civilizatórias. Boletim do Instituto Brasileiro de Ciências Criminais. São Paulo, Boletim no 277, p. 21-22, Dezembro 2015.

DUARTE, Evandro Piza. Paradigmas em criminologia e relações raciais. Cadernos do CEAS, Salvador, n.238, p.500-526, 2016.

FLAUZINA, Ana Luiza Pinheiro. Corpo negro caído no chão: o sistema penal e o projeto genocida do Estado brasileiro. Dissertação (Mestrado em Direito) - Curso de PósGraduação em Direito, Universidade de Brasília, Brasília, 2006.

GIACOMOLLI, Nereu José. Prisão, liberdade e as cautelares alternativas ao cárcere. São Paulo: Marcia Pons, 2013.

; MAYA, André Machado. As medidas cautelares alternativas à prisão: o projeto de reforma do código de processo penal brasileiro e a realidade latino-americana. Revista Duc In Altum Cadernos de Direito, vol. 8, no 14, p. 177-217, jan-abr. 2016.

IBGE. Disponível em: <https://sidra.ibge.gov.br/tabela/3175\#resultado>. Acesso em 16 de outubro de 2018.

KARAM, Maria Lúcia. Legislações proibicionistas em matéria de drogas e danos aos Direitos Fundamentais. Revista Verve, São Paulo, n.12, p. 181-212, 2007.

KHALED JÚNIOR, Salah $\mathrm{H}$. A busca da verdade no processo penal: para além da ambição inquisitorial. 2 ed. Belo Horizonte. Letramento: Casa do Direito, 2016.

LOPES JÚNIOR, Aury. Direito Processual Penal. 11 ed. São Paulo: Saraiva, 2014.

Prisões Cautelares. 5 ed. rev., atual. e ampl. - São Paulo: Saraiva, 2017.

MINAYO, Maria Cecília de Souza (org.). Pesquisa social: teoria, método e criatividade. 28. ed. Petrópolis, RJ: Vozes, 2009.

MARCONI, Marina de Andrade; LAKATOS, Eva Maria. Fundamentos de metodologia científica. 7 ed. São Paulo: Atlas, 2010.

ROSA, Alexandre Morais da. Guia compacto do processo penal conforme a teoria dos jogos. 3 ed. Florianópolis: Empório do Direito, 2016. 
DIAS, Felipe da Veiga; SANTOS, Lucas da Silva. A prisão preventiva em Passo Fundo-RS: análise empírico-criminológica com base nas prisões decretadas em regime de plantão no ano de 2018. Revista Eletrônica Direito e Política, Programa de Pós-Graduação Stricto Sensu em Ciência Jurídica da UNIVALI, Itajaí, v.13, n.3, 30 quadrimestre de 2018. Disponível em: www.univali.br/direitoepolitica - ISSN 1980-7791

SOUZA, Guilherme Augusto Dornelles de; AZEVEDO, Rodrigo Ghiringhelli de. Analisar alternativas à prisão: proposta para superar uma dicotomia. O público e o privado. Ceará, n. 26, pp. 115-138, jul./dez., 2015.

STRECK, Lenio Luiz. O que é isto - decido conforme minha consciência. 2 ed. Porto Alegre: Livraria do Advogado, 2010.

STREVA, Juliana Moreira. Auto de resistência, biopolítica e colonialidade: racismo como mecanismo de poder. Revista Brasileira de Ciências Criminais. vol. 138, dezembro, ano 25. p. 237-267. São Paulo: Revista dos Tribunais, 2017.

ZAFFARONI, Eugenio Raúl. Em busca das penas perdidas: a perda da legitimidade do sistema penal. 5. ed. Rio de Janeiro: Revan, 2001.

Recebido em: 17/09/2018

Aprovado em: 16/10/2018 